\title{
Matric and particulate phosphatase and aminopeptidase activity in limnetic biofilms
}

\author{
Amy J. Thompson, Robert L. Sinsabaugh* \\ Department of Biology, University of Toledo, Toledo, Ohio 43606, USA
}

\begin{abstract}
Biofilms are a major nexus for biogeochemical transformations in inland waters. A defining feature of biofilms is an extracellular polysaccharide matrix. One of the proposed functions of the matrix is retention of extracellular enzymes. We investigated this function by following the kinetics of alkaline phosphatase (AP) and leucine aminopeptidase (LAP) in shaded and exposed limnetic biofilms developed on glass slides. Organic matter (OM) accumulation and chlorophyll content were also measured. Biofilm was scraped from the slides and partitioned in matric and particulate (ectocellular plus detrital bound) fractions. In addition to enzyme activity, the matric fraction was analyzed for carbohydrate and protein content. Over the May to October study period, matric $K_{\mathrm{m}}$ values were significantly higher (by 30 to $50 \%$ ) than particulate values for both enzymes in both treatments $\left(n=44\right.$ ). $V_{\max }$ values were significantly higher in the particulate fraction for both enzymes in both treatments. Matric activity as a fraction of total activity averaged about $25 \%$ (3:1 ratio particulate: matric) for both enzymes, suggesting that the matrix was retaining enzymes. This was corroborated by principal component analysis which in general tied matric enzyme activity with matric carbohydrate and protein content and with $O M$ accumulation and linked phosphatase activity to chlorophyll. There was no correlation between matric and particulate enzyme activities and both varied widely. During periods of seasonal turnover in dominant algal populations, matric activity exceeded particulate. Matric enzymes appear to be a significant community resource whose activity may affect the dynamics of biofilm communities.
\end{abstract}

KEY WORDS: Biofilm · Enzyme activity - Leucine Aminopeptidase · Phosphatase

\section{INTRODUCTION}

Biofilms are complex communities of macro- and microorganisms attached to a surface and enveloped in a microbially produced polysaccharide-rich matrix (Christensen \& Characklis 1991). This matrix, while composed largely of exopolysaccharides (EPS), also contains protein, nucleic acid, and humic compounds. The EPS form a hydrated gel (Jahn \& Neilsen 1993. Costerton et al. 1995); gradients within the matrix lead to the formation of consortia that promote community integration and enhance metabolism (Costerton et al. 1994, Paerl \& Pinckney 1996, Wimpenny \& Colasanti 1997). Proposed functions of the EPS include: an adhesive for the attachment of cells to a surface (Headley et

\footnotetext{
-Corresponding author. E-mail: rsinsab@uoft02.utoledo.edu
}

al. 1995), a lattice that allows heterotrophic and autotrophic organisms to create various microenvironments, an ion exchange medium, a trap for soluble and particulate nutrients, and a diffusion barrier that promotes retention of extracellular enzymes and hydrolyzed substrates (Freeman \& Lock 1995). Dissolved organic matter (DOM) concentrated within the matrix may be more available for microbial utilization because it is in close proximity to the cells and their extracellular enzymes (ZoBell 1943).

For decades it has been proposed that the retention of extracellular enzymes in the immediate environment of the cell increases microbial assimilation of organic and inorganic nutrients. ZoBell (1943) investigated the effect of surfaces on bacterial activity, and pointed out that the accumulation of nutrients at surfaces may be the reason why microbes prefer to grow there. ZoBell (1943) also suggested that the conserva- 
tion of extracellular enzymes may be one consequence of cells packing together at a surface, which may lead to enhanced metabolic efficiency. Lock et al. (1984) in a synthesis on the energy dynamics of epilithic biofilms also proposed that EPS provide a framework where extracellular enzymes, either secreted by algae or bacteria or released by cell lysis and protozoan grazing, are retained to form a system of conserved enzymes that contributes to community metabolism. Lock et al. (1984) suggested that extracellular enzymes become attached to EPS through processes similar to the formation of enzyme-humus complexes in soil. Such complexes can allow enzymes access to their substrates while protecting them from degradation (Wetzel 1991). More recent studies in planktonic systems have linked extracellular enzyme activity to substrate uptake (Hoppe et al. 1988, Chróst 1991), but it remains to be shown that the biofilm matrix actually functions as a reservoir for enzymes.

Two of the most studied extracellular enzymes in freshwater systems are alkaline phosphatase (AP) and leucine aminopeptidase (LAP) (Halemejko \& Chróst 1984, Jansson et al. 1988, Sinsabaugh \& Linkins 1988, Chróst 1991, Marxsen \& Schmidt 1993). AP degrades phosphomonoesters into orthophosphate. Bacteria, phytoplankton, and zooplankton contribute phosphatase to the environment; secretion of phosphatases by living bacteria appears to be less common than for algae (Jansson et al. 1988). Many studies have been done on phosphatase activity with respect to environmental nutrient availability. Cotner \& Wetzel (1991) looked at bacterial phosphatases in 3 different habitats (epipelic, pelagic, and epiphytic) in a moderately eutrophic lake. They found that epipelic strains had the greatest substrate affinity (low $K_{\mathrm{m}}$ ) and the greatest hydrolysis potential ( $\left.V_{\max }\right)$. Chróst (1991) compared the kinetics of cell bound and extracellular phosphatase, peptidase, and glucosidase in lake water and found that 85 to $92 \%$ of the total enzyme activity was associated with the cell surface, indicating a tight coupling of hydrolysis to uptake.

Peptides are a significant source of nitrogen in aquatic systems (Jørgensen 1987, McCarthy et al 1998). In one of the earliest studies, Hollibaugh \& Azam (1983) concluded that dissolved proteases in seawater were not important in protein degradation because close contact of the cell with the protein was necessary. Several studies have correlated peptidase activities with substrate availability, substrate uptake and bacterial productivity (e.g. Hoppe et al. 1988, Münster 1991, Müller-Niklas et al. 1994, Sinsabaugh et al. 1997, Foreman et al. 1998). Jacobsen \& Rai (1991) reported that LAP activity increased with the degree of lake eutrophication. Kroer et al. (1994) found that specific LAP activities were similar among marine, estuar- ine and riverine bacterioplankton despite wide differences in the concentration of inorganic N. Similar observations were made by Sinsabaugh et al. (1997) in a comparison of 3 large rivers. Müller-Niklas et al. (1994) reported that cell-specific activities of LAP and other enzymes were similar for bacteria associated with marine snow and for those suspended in the surrounding seawater.

In this study, we compared the ectocellular and matric activities of AP and LAP in limnetic biofilms to assess whether the EPS retains extracellular enzymes. We hypothesized that the kinetic differences between matric and ectoenzymes may affect microbial utilization of organic matter within the biofilm.

\section{METHODS}

Site description. The sampling site was a small eutrophic pond. During the spring, maximal water depth is about $1 \mathrm{~m}$ and during July and August the pond shrinks to a maximal depth of $0.5 \mathrm{~m}$. From midJune through early September thick algal mats and submergent macrophytes dominate the system. Over our May to November sampling period, water temperature ranged from 4 to $25^{\circ} \mathrm{C}$, $\mathrm{pH}$ varied from 6.7 to 7.6 , total phosphorus ranged from undetectable to $7.1 \mu \mathrm{M}$, nitrate $-\mathrm{N}$ varied from 300 to $600 \mu \mathrm{M}$, and nitrite- $\mathrm{N}$ ranged from 2 to $9 \mu \mathrm{M}$.

Sampling units. Shaded and exposed biofilms were grown on glass slides for 1 mo intervals. Slide racks holding 20 microscope slides were suspended $15 \mathrm{~cm}$ below the surface from styrofoam rings. For half the sampling units, a black plastic lid (50 $\mathrm{cm}$ diameter) was placed over the styrofoam float to shade the slide rack. The remaining units were left uncovered, exposing the slide racks to direct sunlight. The first set of units (1 shaded and 1 exposed) was deployed on 3 April 1996 and the second set 2 wk later. Each unit was left in the pond for $4 \mathrm{wk}$ and sampling occurred every $2 \mathrm{wk}$ from 13 May to 19 November 1996 . On those respective sampling dates, the slide racks were recovered and placed in a bucket of pond water for transport back to the laboratory $(8 \mathrm{~km}$ away), and new racks were attached to each sampling unit for biofilm colonization. Sample processing began immediately upon return to the laboratory.

Biofilm extraction and EPS separation. Using a razorblade, biofilms were scraped from 12 slides (total surface area $450 \mathrm{~cm}^{2}$ ) into a glass dish containing $40 \mathrm{ml}$ of a $50 \mathrm{mM}$ sodium bicarbonate buffer $(\mathrm{pH} 8)$. The biofilm suspension was dispersed using a Brinkmann tissue homogenizer fitted with an $8 \mathrm{~mm}$ diameter probe. The suspension was centrifuged at $10000 \times g$ for $30 \mathrm{~min}$ at $4^{\circ} \mathrm{C}$. Following centrifugation, the supernatant containing the 
dispersed EPS matrix was decanted and chilled on ice. The pellet consisting of microbial cells and other particulate material was resuspended in $50 \mathrm{mM}$ bicarbonate buffer and chilled. Enzyme assays began immediately following extract preparation.

Enzyme analysis. 4-methylumbelliferyl phosphate and L-leucine 7-amido-4-methyl coumarin (Sigma) were used as substrates for assays of matric and particulate AP and LAP activities. The assays were conducted in 96 -well black microplates by mixing $200 \mu \mathrm{l}$ of sample with $50 \mu \mathrm{l}$ of substrate solution; there were 5 analytical replicates per sample. Negative controls combined $200 \mu \mathrm{l}$ of bicarbonate buffer with $50 \mu \mathrm{l}$ of substrate. Quench effects were quantified by adding a series of 4 -methylumbelliferone and 7 -amino-4-methyl coumarin standards to both samples and buffer. Immediately after the solutions were combined, the initial fluorescence values were recorded using a Dynatech Microfluor platereader (excitation $365 \mathrm{~nm}$, emission $450 \mathrm{~nm}$ ). Additional fluorescence readings were taken every $30 \mathrm{~min}$. To obtain kinetic data, AP activity was assayed at final substrate concentrations (substrate concentrations in the microfluor plate wells) ranging from 1 to $120 \mu \mathrm{M}$, and LAP at final concentrations ranging from 5 to $120 \mu \mathrm{M}$. The Michaelis-Menton kinetic parameters, $K_{\mathrm{m}}$ and $V_{\max }$, were determined for each enzyme using the Eadie-Hofstee regression:

$$
V=V_{\text {max }}-K_{\mathrm{m}}(V /[S])
$$

where $K_{\mathrm{m}}$ is the half-saturation constant for the enzyme, $V_{\max }$ is the highest rate of substrate hydrolysis, and $[S]$ is the substrate concentration.

Enzyme activities were expressed as $\mu \mathrm{mol} \mathrm{h} \mathrm{h}^{-1} \mathrm{~cm}^{-2}$ using micromolar emission coefficients calculated from regressions of fluorescence versus product concentration (4-methylumbelliferone for AP and 7-amino-4methyl coumarin for LAP). All activities were corrected for quenching.

Biofilm composition. Protein concentration in the matrix samples was estimated by the Bradford assay. The results were expressed as $\mu \mathrm{g} \mathrm{cm}^{-2}$ with bovine serum albumin (BSA) as the standard (Bradford 1976). Matric carbohydrate concentration was estimated by the phenol-sulfuric acid method with glucose as the standard (Underwood et al. 1995). Results were presented as $\mu \mathrm{g} \mathrm{cm}^{-2}$. Chlorophyll a concentration, reported as $\mu \mathrm{g} \mathrm{cm}^{-2}$, was determined by scraping 4 slides $\left(150 \mathrm{~cm}^{2}\right)$ into $30 \mathrm{ml}$ of $90 \% \mathrm{MgCO}_{3}$-saturated acetone. The suspensions were held in the dark for $24 \mathrm{~h}$ at $4^{\circ} \mathrm{C}$. Optical density was measured according to the procedure in Standard Methods (Anonmyous 1999). Organic matter concentration, expressed as $\mu \mathrm{g} \mathrm{cm}^{-2}$ of ash-free dry mass (AFDM), was determined by drying 4 slides $\left(37.5 \mathrm{~cm}^{2}\right.$ per slide) at $65^{\circ} \mathrm{C}$, weighing, ashing at $500^{\circ} \mathrm{C}$, and weighing again.

\section{RESULTS}

AFDM ranged from 54 to $1900 \mu \mathrm{g} \mathrm{cm} \mathrm{cm}^{-2}$ in the exposed biofilm, and from 14 to $310 \mu \mathrm{g} \mathrm{cm}^{-2}$ in the shaded biofilms (Fig. 1). In both treatments, AFDM peaked on 15 August (Day 95) and was minimal on 29 October (Day 170). The maxima coincided with the appearance of chironomid retreats on both the shaded and exposed biofilms. AFDM was positively correlated with matric carbohydrate and matric protein concentration in the shaded community ( $r=0.94$ and 0.88 , respectively, $n=13, p<0.05$ ), and negatively correlated with matric carbohydrate and chlorophyll con-
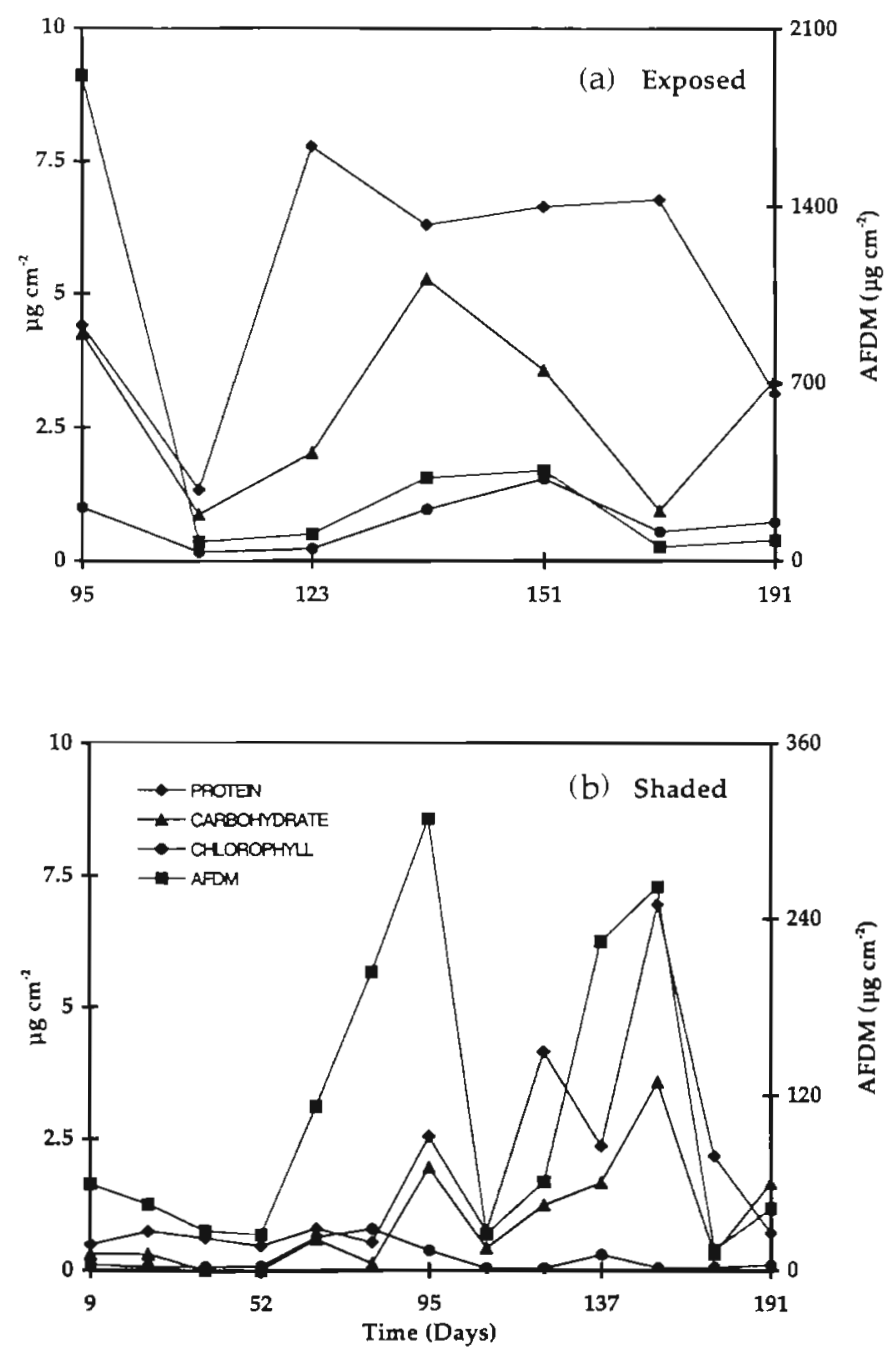

Fig. 1. (a) Protein, carbohydrate, chlorophyl and ash-free dry mass (AFDM) for sunlight-exposed biofilms sampled from glass slides in a eutrophic pond between 15 August (Day 95) and 19 November 1996 (Day 191). (b) Structural components of shaded biofims sampled between 21 May (Day 9) and 19 November (Day 191) 
Table 1. Correlation coefficients from a principal component analysis of the structural characteristics (protein, carbohydrate and chlorophyll concentration, and AFDM) of shaded and exposed biofilms

\begin{tabular}{|lcccc|}
\hline \multirow{2}{*}{ Component } & \multicolumn{2}{c}{ Shaded } & \multicolumn{2}{c|}{ Exposed } \\
& Factor 1 & Factor 2 & Factor 1 & Factor 2 \\
\cline { 1 - 1 } Protein & 0.88 & & & 0.89 \\
Carbohydrate & 0.94 & & -0.89 & \\
Biomass & 0.83 & & -0.88 & \\
Chlorophyl & & -0.98 & -0.68 & \\
Variance (\%) & 59 & 34 & 53 & 27 \\
\hline
\end{tabular}

centration ( $\mathrm{I}=-0.89$ and -0.68 respectively, $\mathrm{n}=8, \mathrm{p}<$ 0.05 ) in the exposed biofims (Table 1 ).

Chlorophyll concentration in the exposed biofilm ranged from 0.16 to $1.50 \mu \mathrm{g} \mathrm{cm}^{-2}$ and from 0.04 to $0.79 \mu \mathrm{g} \mathrm{cm}^{-2}$ in the shade (Fig. 1a,b). In the exposed community, peaks occurred on Day 95 (15 August) and on Day 151 (10 October). In the shaded community, peaks occurred on Day 81 (1 August) and on Day 137 (26 September). Chlorophyll, in the shaded treatment was not correlated with AFDM, matric protein or matric carbohydrate (Fig. 2a), suggesting that the matrix was largely a heterotrophic construct. In the exposed biofilm, chlorophyll negatively correlated with matric carbohydrate and AFDM ( $r=-0.89$ and -0.88 respectively, $\mathrm{n}=8, \mathrm{p}<0.05$ ) (Fig. $2 \mathrm{~b}$ ), again suggesting a tradeoff between heterotrophic and autotrophic organization.

Matric protein concentration ranged from 0.47 to $6.93 \mu \mathrm{g} \mathrm{cm}^{-2}$ (Days 52 and 151, respectively) in the shaded biofilms, and from 1.33 to $7.76 \mu \mathrm{g} \mathrm{cm}^{-2}$ (Days 109 and 123, respectively) in the exposed ones (Fig. 1a,b). Carbohydrate concentration was similar to protein content, ranging from 0.01 to $3.59 \mathrm{\mu g} \mathrm{\textrm {cm } ^ { - 2 }}$ (Days 52 and 151, respectively) in the shaded samples, and from 0.87 to $5.28 \mu \mathrm{g} \mathrm{cm}^{-2}$ (Days 109 and 137, respectively) in the exposed ones. Protein content in the extracellular matrix was correlated with carbohydrate concentration only in the shaded community (Fig. 2a).
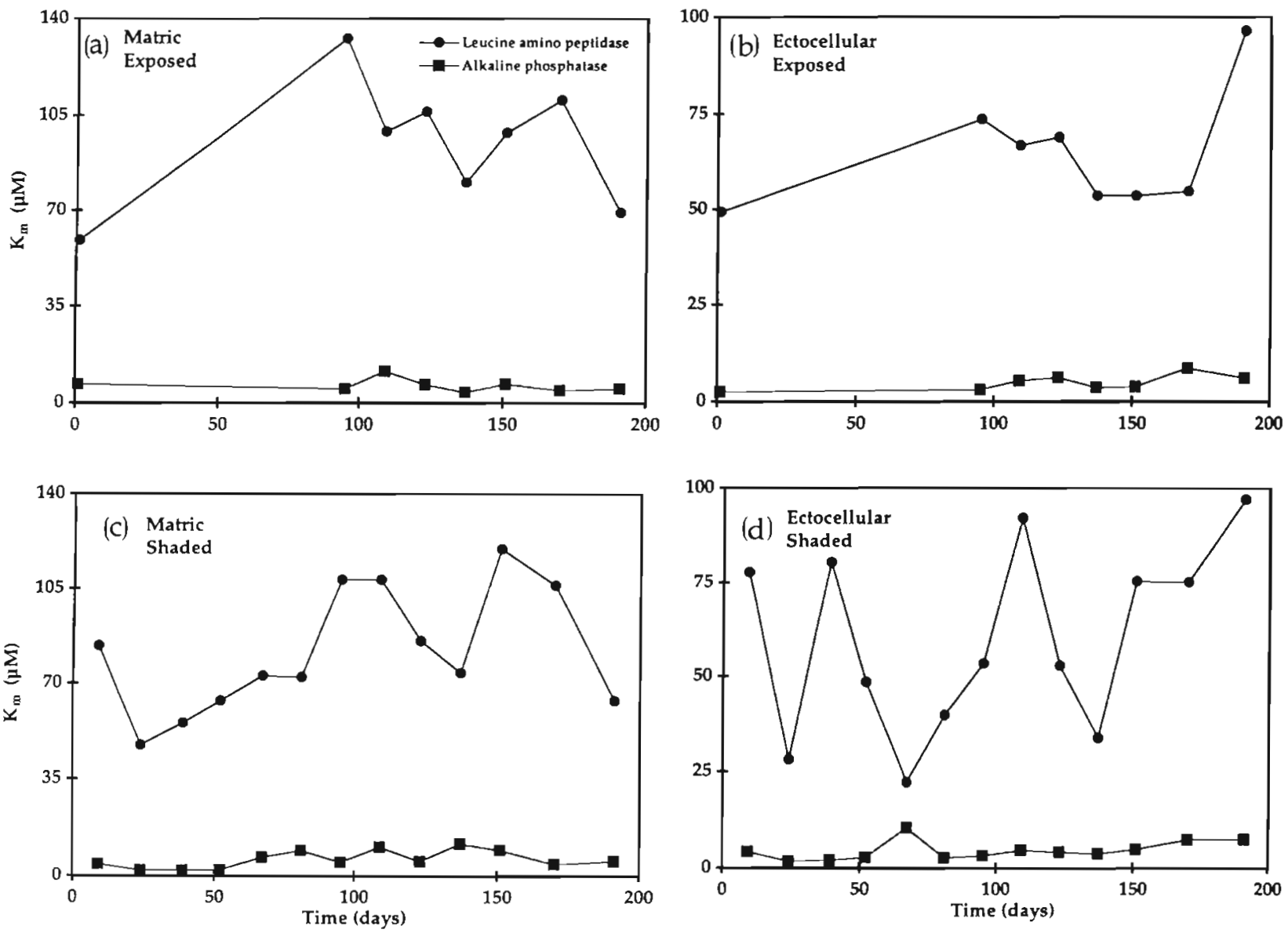

Fig. 2. (a,b) Principal component analysis (PCA) of structural data from exposed and shaded biofilm samples. (c,d) PCA factor plots for enzyme parameters in relation to biofilm structural characteristics 
Eadie-Hofstee regressions were used to calculate the kinetic parameters $K_{\mathrm{m}}$ and $V_{\max }$ for phosphatase and aminopeptidase. For matric peptidase, all regressions were statistically significant $(\alpha<0.05)$; $\mathrm{r}^{2}$ values ranged from 0.82 to 0.99 . For particle-bound peptidase, the regressions for shaded biofilms on Days 52 (3 July) and 81 (1 August) were not significant; the rest had $\mathrm{r}^{2}$ values ranging from 0.71 to 0.94 . For matric phosphatase, the Day 81 (1 August) regression for the shaded treatment was not statistically significant; the other phosphatase regressions had $r^{2}$ values from 0.50 to $0.96(\alpha<0.05)$.

The $K_{\mathrm{m}}$ values of matric enzymes were generally higher than those of particle-associated enzymes (Fig. 3). In the exposed treatment, matric $K_{\mathrm{m}}$ ranged from 59 to $110 \mu \mathrm{M}$ (mean $95 \mu \mathrm{M}$ ) for peptidase and from 3 to $12 \mu \mathrm{M}$ (mean $6.3 \mu \mathrm{M}$ ) for phosphatase (Fig. 2a). Particulate $K_{\mathrm{m}}$ in the exposed treatment ranged from 49 to $100 \mu \mathrm{M}$ (mean $65 \mu \mathrm{M}$ ) for peptidase and from 2 to $9 \mu \mathrm{M}$ (mean $5.0 \mu \mathrm{M}$ ) for phosphatase (Fig. $3 \mathrm{~b}$ ). $K_{\mathrm{m}}$ values in the shaded treatment followed similar trends. In the matric fraction, $K_{\mathrm{m}}$ ranged from 47 to $120 \mu \mathrm{M}$ (mean $82 \mu \mathrm{M}$ ) for peptidase and from 2 to $12 \mu \mathrm{M}$ (mean $6.1 \mu \mathrm{M}$ ) for phosphatase (Fig. $3 \mathrm{c}$ ). Particulate $K_{\mathrm{m}}$ values ranged from 22 to $100 \mu \mathrm{M}$ (mean $60 \mu \mathrm{M}$ ) for peptidase and from 1 to $11 \mu \mathrm{M}$ (mean $4.6 \mu \mathrm{M}$ ) for phosphatase (Fig. 3d).

$V_{\max }$ values showed strong seasonal trends in both treatments (Fig. 4). Matric activity followed a bimodal pattern with maxima around Days 100 and 150 (Fig. 4a). Matric peptidase activity ranged from 0.5 to $7.5 \mathrm{nmol} \mathrm{h}^{-1} \mathrm{~cm}^{-2}$ (mean 2.5) in the exposed treatment, and from 0.1 to $7.0 \mathrm{nmol} \mathrm{h}^{-1} \mathrm{~cm}^{-2}$ (mean 1.4) in the shaded (Fig. $4 \mathrm{a}, \mathrm{c}$ ). Matric phosphatase activity ranged from 0.1 to $5.0 \mathrm{nmol} \mathrm{h}^{-1} \mathrm{~cm}^{-2}$ (mean 2.6) in the exposed biofilms and from 0.1 to $3.5 \mathrm{nmol} \mathrm{h}^{-1} \mathrm{~cm}^{-2}$ (mean 0.9) in the shaded samples (Fig. $4 \mathrm{a}, \mathrm{c}$ ).

In general, $V_{\max }$ values for particulate activity were higher than those for matric activity. Peptidase $V_{\max }$ ranged from 0.11 to $100 \mathrm{nmol} \mathrm{h}^{-1} \mathrm{~cm}^{-2}$ (mean 17.4) in the exposed treatment and from 0.10 to $50 \mathrm{nmol} \mathrm{h}{ }^{-1}$ $\mathrm{cm}^{-2}$ (mean 9.6) in the shade. Phosphatase activity in the particulate fraction ranged from 0.08 to $70 \mathrm{nmol} \mathrm{h}^{-1}$ $\mathrm{cm}^{-2}$ (mean 23.5) in the exposed and from 0.10 to $50 \mathrm{nmol} \mathrm{h}^{-1} \mathrm{~cm}^{-2}$ (mean 11.44) in the shaded treatment. In general, these large ranges for $V_{\max }$ arise from a small number of extreme values. The low ranges were
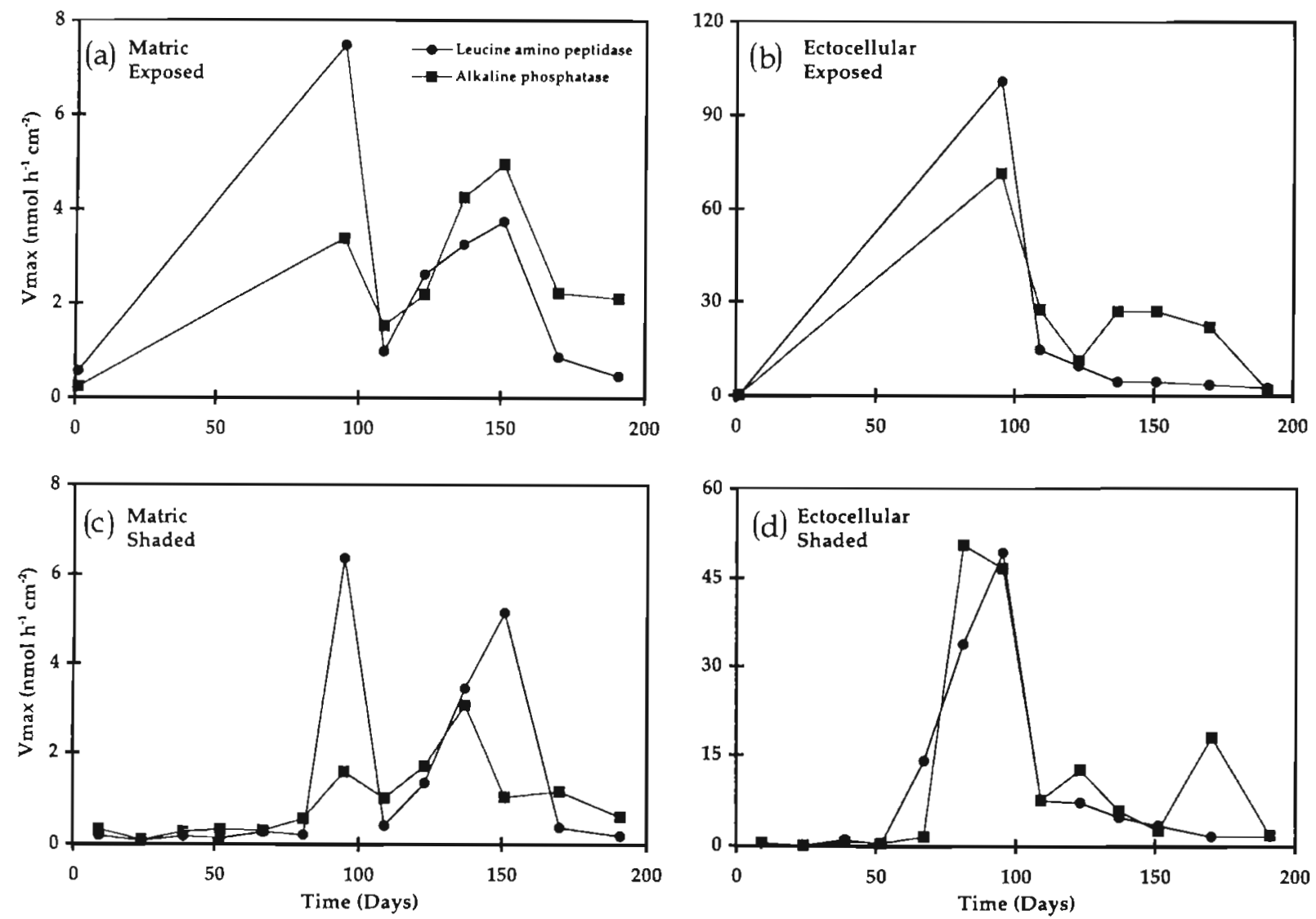

Fig. 3. (a to d) Half saturation constants $\left(K_{m}\right)$ for matric and particulate LAP and alkaline phosphatase in exposed and shaded biofilms sampled from 13 May (Day 0) to 19 November (Day 191) 

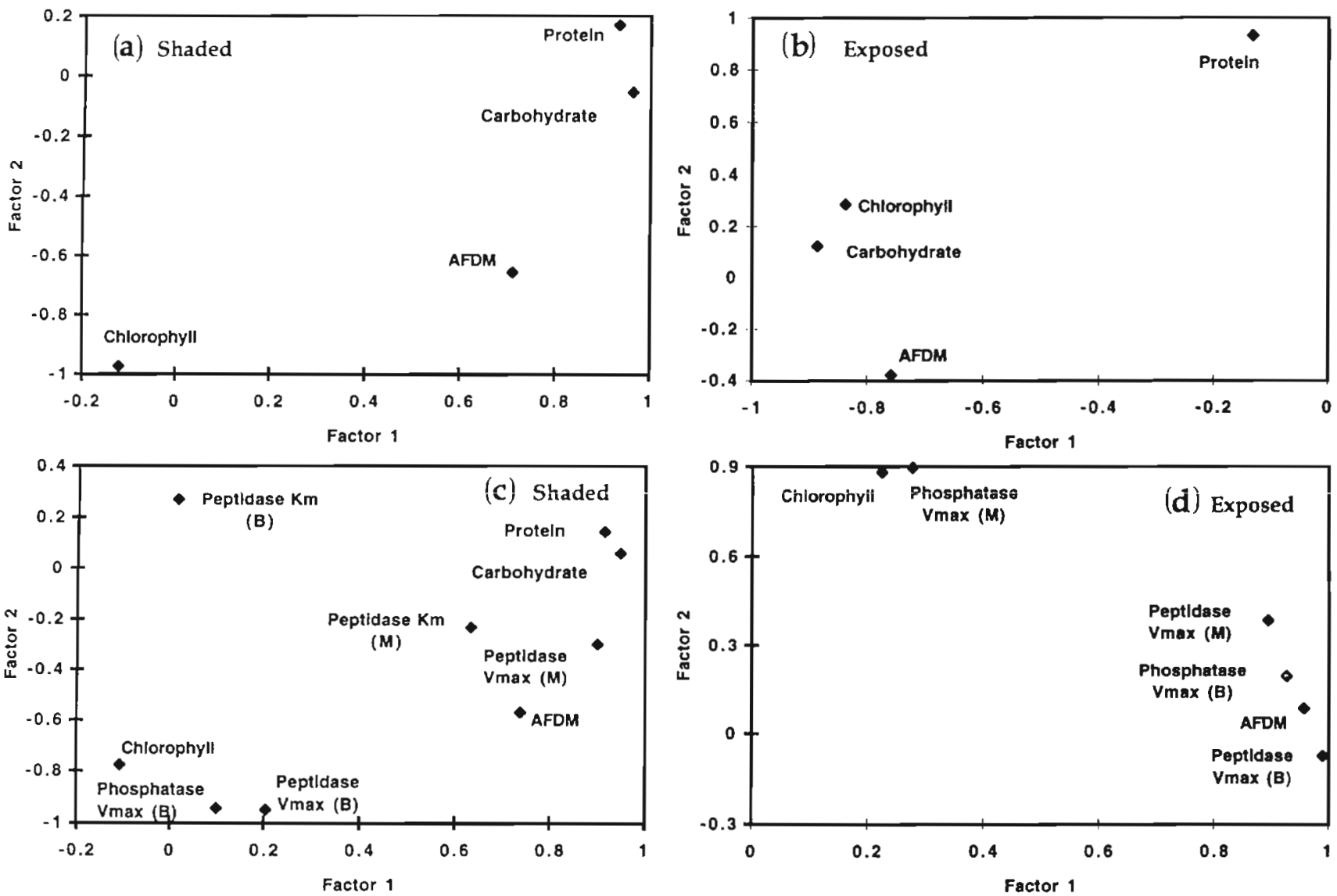

Fig. 4. (a to d) $V_{\max }$ values for matric and particulate LAP and alkaline phosphatase from exposed and shaded biofilms cultured on glass slides in a eutrophic pond

generally found in early season samples; the high ranges were associated with the chironomid colonization of late summer.

For LAP, matric $K_{\mathrm{m}}$ values were significantly higher than particulate values, and particulate $V_{\max }$ values were significantly higher than matric $V_{\max }$ values (MANOVA on log-transformed data, $\mathrm{p}<0.05$ ). Light exposure did not significantly increase $K_{\mathrm{m}}$ or $V_{\max }$ relative to shaded biofilms. Alkaline phosphatase showed similar trends: matric $K_{\mathrm{m}}$ values were significantly higher at a $90 \%$ confidence level ( $\mathrm{p}<0.1$ ) than particulate values, and particulate $V_{\max }$ values were significantly higher than their matric counterparts (MANOVA on log transformed data, $p<0.05)$. Unlike peptidase, light exposure significantly increased phosphatase $V_{\max }$ values relative to the shaded treatment but did not affect $K_{\mathrm{m}}$ values.

When biofilm composition and enzyme parameters were combined in a principal component analysis, matric protein, matric carbohydrate, AFDM, matric peptidase $V_{\text {max }}$ and matric peptidase $K_{\mathrm{m}}$ all loaded on the first component, accounting for $40 \%$ of the variance in the shaded biofilms. The second component, which explained an additional $33 \%$ of the variance, grouped chlorophyll with particulate peptidase $V_{\max }$ and particulate phosphatase $V_{\max }$ (Fig. 2c, Table 2). In the exposed biofilm, $61 \%$ of the variance was explained by the first factor which grouped AFDM,

Table 2. Correlation coefficients from a principal component analysis of the structural and enzymic characteristics of a shaded biofilm grown in a eutrophic pond

\begin{tabular}{|lccc|}
\hline Component & Factor 1 & Factor 2 & Factor 3 \\
\hline Protein & 0.91 & & \\
Carbohydrate & 0.95 & & \\
AFDM & 0.74 & -0.78 & \\
Chlorophyll & & -0.95 & \\
$\begin{array}{l}\text { Peptidase } V_{\max }(\mathrm{M}) \\
\text { Peptidase } V_{\max }(\mathrm{B})\end{array}$ & 0.9 & -0.94 & \\
Phosphatase $V_{\max }(\mathrm{B})$ & & & -0.89 \\
Peptidase $K_{\mathrm{m}}(\mathrm{M})$ & 0.64 & 33 & 16 \\
$\begin{array}{l}\text { Peptidase } K_{\mathrm{m}}(\mathrm{B}) \\
\text { Variance }(\%)\end{array}$ & 40 & & \\
\hline
\end{tabular}


Table 3. Correlation coefficients from a principal component analysis of the structural and enzymic characteristics of an exposed biofilm grown in a eutrophic pond

\begin{tabular}{|lcc|}
\hline Component & Factor 1 & Factor 2 \\
\hline AFDM & 0.96 & \\
Chlorophyll & 0.89 & 0.88 \\
Peptidase $V_{\max }(\mathrm{M})$ & 0.99 & \\
Peptidase $V_{\max }(\mathrm{B})$ & 0.93 & \\
Phosphatase $V_{\max }(\mathrm{B})$ & & 0.9 \\
Phosphatase $V_{\max }(\mathrm{M})$ & 61 & 30 \\
Variance (\%) & & \\
\hline
\end{tabular}

matric peptidase $V_{\max }$ particulate peptidase $V_{\max }$, and particulate phosphatase $V_{\max }$. Chlorophyll and matric phosphatase $V_{\max }$ loaded heavily on factor 2, which accounted for $30 \%$ of the variance (Fig. 2d, Table 3). While light did have a large effect on biofilm development, the structural differences between the shaded and exposed biofilms had little effect on the activity and kinetics of LAP and AP.

\section{DISCUSSION}

Our protocol for separating matric and particulate enzymes by homogenization and centrifugation of biofilm samples was necessarily coarse. The procedure was relatively mild (no detergents or sonication) and was intended to release matric enzymes into solution while minimizing cell lysis and solubilization of ectoenzymes. Consequently, the particulate fraction is procedurally defined as material associated with particles sedimenting at $10000 \times g$ which includes the ectoenzymes of living cells, but also enzymes associated with cell fragments and detritus.

The exposed and shaded biofilm communities were structurally distinct as evidenced by the differing correlation patterns among chlorophyll, matric carbohydrate, matric protein and AFDM. But they were functionally similar in terms of their organization at the enzyme level. $K_{\mathrm{m}}$ and $V_{\max }$ for LAP and $K_{\mathrm{m}}$ for AP showed similar ranges in both treatments. The partitioning of activity between matric and particulate fractions was similar among treatments. Seasonal trends were similar. The only difference was that phosphatase $V_{\max }$ was significantly higher in the light-exposed samples, which was not unexpected since algae are major producers of phosphatase. Sinsabaugh \& Linkins (1988) studied shaded and exposed biofilms in a boreal river and also reported that autotrophic and heterotrophic communities showed similar temporal and organizational patterns in enzyme activites ( $\alpha$-glucosidase, $\beta$-glucosidase, $\beta$-N-acetylglucosaminidase, $\beta$-xylosidase, protease, cellobiohydrolase, phenol oxidase, phosphatase, sulfatase).

In both communities, the matrix appeared to act as a reservoir for extracellular enzymes. When matric activity was expressed as a fraction of total activity (matric plus particulate) for each sample, matric activity accounted for $30 \%$ of the LAP activity in the biofilm, on average (range 6 to $84 \%$ ) for the light exposed samples and for $23 \%$ of total activity, on average (range 0.6 to $63 \%$, in the shaded samples. For AP, matric activity averaged about $24 \%$ of total activity in both treatments, with a range of 3 to $74 \%$. These $1: 3$ ratios of matric to particulate activity are lower than the 1:9 ratios of dissolved to particulate activity observed for planktonic communities (Chróst 1991). Combined with the findings that matric activity in some cases exceeded particulate activity and that matric activity correlated with measures of matrix density, the data suggest that the EPS matrix does play a role in enzyme retention.

There are several possible mechanisms for retention: covalent bonding, electrostatic bonding, polymer entrapment, hydrophobic interactions and hindered diffusion (Christensen \& Characklis 1991). We did not try to resolve these, but we did find that matric carbohydrate and AFDM densities positively correlated with matric peptidase activities, while phosphatase activities appeared to be most closely linked to chlorophyll, which suggests that the retention mechanisms for the 2 enzymes may differ.

On average, matric $K_{\mathrm{m}}$ values were about a third higher than those of particulate enzymes. One explanation for this phenomenon is that some of the resident populations secrete enzymes directly into the environment. In that case, matric enzymes with higher $K_{\mathrm{m}}$ values than ectocellular enzymes might be considered adaptive: a strategy for maximizing nutrient acquisition as long as the released enzymes remain in proximity to the cell, which in turn suggests they may have EPS binding sites. The alternative to design is that the effect is an artifact of diagenesis: ectocellular and intracellular enzymes released into the environment are conformationally constrained by reactions with the EPS, humics or other molecules which reduce their substrate binding capability. The latter explanation seems more likely and parallels the humification reactions that alter the kinetics of soil enzymes.

Within biofilms, matric enzymes may work in conjunction with cell-bound enzymes to hydrolyze substrates near the cell and thereby contribute to community metabolism. In most of our samples, most of the enzyme activity was associated with particles. Matric activity was lower in terms of $V_{\max }$ and matric enzymes had lower substrate affinities, as measured by $K_{\mathrm{m}}$. This organization suggests that on average matric enzymes 
are not competing strongly with ectocellular enzymes for substrates, but they may act to increase microbial substrate uptake by increasing concentration gradients for assimilable nutrients.

This scenario, which describes the 'mean' state of biofilm organization, is consistent with the models presented by ZoBell (1943) and Lock et al. (1984). However, it is important to emphasize that both matric and ectocellular enzyme activities varied widely and that there was no correlation between matric enzyme parameters and particulate enzyme parameters. The decoupling of matric and particulate activities means a number of functional states are possible and perhaps the most interesting ones occur when the 'mean' pattern breaks, i.e. when matric $V_{\max }>$ ectocellular $V_{\max }$ or when matric $K_{\mathrm{m}}<$ ectocelluiar $K_{\mathrm{m}}$. In this sludy, such breaks coincided with periods of turnover in biofilm composition that occurred at the end of August and in late November. These turnovers were forced by seasonal succession in dominant algal taxa, which shift from diatoms in the spring to chlorophytes in the summer and to cyanobacteria in the autumn. We speculate that during each stage of seasonal succession a 'normal' biofilm organization appears, i.e. one in which matric activity < ectocellular and matric $K_{\mathrm{m}}>$ ectocellular $K_{\mathrm{m}}$, but during periods of transition from one dominant algal assemblage to another, biofilm organization becomes chaotic. Enzyme release through cell lysis and successional shifts in bacterial populations brought about by changes in substrate availability are likely driving mechanisms. Shifts in enzyme activity and kinetics in response to algal senescence have also been reported for planktonic systems (Halemejko \& Chróst 1986, Jansson et al. 1988, Chróst 1991). It is likely that disruptions in biofilm functional organization also accompany other types of disturbance such as grazing.

Matric enzymes are a community resource, uncoupled from the metabolism of individual cells. Their activity can comprise a significant fraction, sometimes even most, of the biofilm total. This store of enzymes may contribute to the integration of biofilm populations into functional consortia and, in successional terms, may facilitate population turnovers.

Acknowledgements. We thank the Stranahan Arboretum for allowing us to use their pond as a sampling site.

\section{LITERATURE CITED}

Anonymous (1999) Standard methods for the examination of water and wastewater, 20th edn. American Water Works Association, American Public Health Association, Water Pollution Control Federation, Washington, p 1067-1073

Bradford $M$ (1976) A rapid and sensitive method for the quantitation of microgram quantities of protein utilizing the principle of protein-dye binding. Anal Biochem 72: $248-254$

Christensen BE, Characklis WG (1991) Physical and chemical properties of biofilms. In: Characklis WG (ed) Biofilms. John Wiley \& Sons, New York, p 93-108

Chróst R (1991) Environmental control of the synthesis and activity of aquatic microbial ectoenzymes. In: Chróst RJ (ed) Microbial enzymes in aquatic environments. Springer-Verlag, New York, p 29-51

Costerton W J, DeBeer D. Lewandowski Z (1994) Biofilms, the customized niche. J Bacteriol 176:2137-2142

Costerton WJ, Lewandowski Z, Caldwell DE, Korber DR, Lappin-Scott HM (1995) Microbial biofilms. Annu Rev Microbiol 49:711-745

Cotner JB, Wetzel RG (1991) Bacterial phosphatases from different habitats in a small, hardwater lake. In: Chrost RJ (ed) Microbial enzymes in aquatic environments. Springer-Verlag, New York, p 187-202

Foreman C.M, Franchini $P_{i}$ Sinsabaugh RL (1998) The trophic dynamics of riverine bacterioplankton: relationships among substrate availability, ectoenzyme kinetics and growth. Limnolo Oceanogr 43:1344-1352

Freeman C, Lock M (1995) The biofilm polysaccharide matrix: a buffer against changing organic substrate supply? Limnol Oceanogr 40:273-278

Halemejko GZ, Chróst RJ (1984) The role of phosphatase in phosphorus mineralization during decomposition of lake phytoplankton blooms. Arch Hydrobiol 101:489-502

Halemejko GZ, Chróst RJ (1986) Enzymatic hydrolysis of proteinaceous particulate and dissolved material in a eutrophic lake. Arch Hydrobiol 107:1-21

Headley JV, Peru KM, Lawrence JR, Wolfaardt GM (1995) MS/MS identification of transformation products in degradative biofilms. Anal Chem 67:1831-1837

Hollibaugh JT, Azam F (1983) Microbial degradation of dissolved proteins in seawater. Limnol Oceanogr 28: $1104-1116$

Hoppe H, Kim S, Gocke K (1988) Microbial decomposition in aquatic environments: combined process of extracellular enzyme activity and substrate uptake. Appl Environ Microbiol 54:784-790

Jacobsen TR, Rai H (1991) Aminopeptidase activity in lakes of differing eutrophication. In: Chróst RJ (ed) Microbial enzymes in aquatic environments. Springer-Verlag, New York, p 155-163

Jahn A, Neilsen PH (1993) Extraction of extracellular polymeric substances (EPS) from biofilms using a cation exchange resin. Water Sci Technol 32:157-164

Jansson M, Olsson H, Pettersson K (1988) Phosphatases; origin, characteristics, and function in lakes. Hydrobiologia 170:157-175

Jørgensen NOG (1987) Free amino acids in lakes: concentrations and assimilation rates in relation to phytoplankton and bacterial production. Limnol Oceanogr 32:97-111

Kroer N, Jørgensen NOG, Coffin RB (1994) Utilization of dissolved nitrogen by heterotrophic bacterioplankton: a comparison of three ecosystems. Appl Environ Microbiol 60: $4116-4123$

Lock MA, Wallace RR, Costeron JW, Ventullo RM, Chariton SE (1984) River epilithon: toward a structural-functional model. Oikos 42:10-22

Marxsen J, Schmidt H (1993) Extracellular phosphatase activity in sediments of the Breitenbach, a Central European mountain stream. Hydrobiologia 253:207-216

McCarthy MD, Benner R, Hedges JI (1998) Major bacterial contribution to marine dissolved organic nitrogen. Science 281:231-234 
Müller-Niklas G, Schuster S, Kaltenböck E, Herndl GJ (1994) Organic content and bacterial metabolism in amorphous aggregations of the northern Adriatic Sea. Limnol Oceanogr 39:58-68

Münster U (1991) Extracellular enzyme activity in eutrophic and polyhumic lakes. In: Chróst RJ (ed) Microbial enzymes in aquatic environments. Springer-Verlag, New York, p 25-59

Paerl HW, Pinckney JL (1996) A mini-review of microbial consortia: their roles in aquatic production and biogeochemical cycling. Microb Ecol 31:225-247

Sinsabaugh RL, Linkins AE (1988) Exoenzyme activity associated with lotic epilthon. Freshw Biol 20:249-261

Sinsabaugh RL, Findlay S, Franchini P, Fischer D (1997) Enzy-

Editorial responsibility: Karel Simek

Ceské Budějovice, Czech Republic matic analysis of riverine bacterioplankton production Limnol Oceanogr 42:29-38

Underwood GJC, Paterson DM, Parkes RJ (1995) The measurement of microbial carbohydrate exopolymers from intertidal sediments. Limnol Oceanogr 40:1243-1253

Wetzel RG (1991) Extracellular enzymatic interactions: storage, redistribution, and interspecific communication. In: Chróst RJ (ed) Microbial enzymes in aquatic environments. Springer-Verlag, New York, p 6-25

Wimpenny JWT, Colasanti R (1997) A unifying hypothesis for the structural of microbial biofilms based on cellular automaton models. FEMS Microbiol Ecol 22:1-16

ZoBell CE (1943) The effect of solid surfaces upon bacterial activity. J Bacteriol 46:39-56

Submitted: August 30, 1999; Accepted: February 1, 2000 Proofs received from author(s): March 22, 2000 